\title{
TÜRK GIDA KODEKSİNE GÖRE GIDA ETİKETİ OKURYAZARLIĞININ BELİRLENMESİ: GENÇ TÜKETICIILER ÜZERINNDE BİR ARAŞTIRMA
}

Yildiray KIZGIN 1

Bekir TUNCER 2

\author{
Received Date (Başvuru Tarihi): \\ Accepted Date (Kabul Tarihi): \\ Published Date (Yayın Tarihi):
}

$9 / 04 / 2020$

$2 / 06 / 2020$

$25 / 06 / 2020$

Çalıșmada ilk yazar Sorumlu Yazar (Corresponding Author) rolündedir.

$\ddot{O Z Z}$

\section{Anahtar Kelimeler: \\ Gida Etiketi}

Gıda Etiketi Okuryazarliğı

Genç Tüketici

JEL Kodları:

M38

M39

Q18
Gelecekte sağlıklı toplumların inşaası için doğru beslenmenin önemi aşikardır. Bu çalışmada özellikle paketli gıdalarn günümüz gıda tüketimi içerisinde önemli bir yere sahip olduğu gerçeğinden hareketle, geleceğin yetişkinleri olacak gençlerin gıda etiketi okuryazarlığını ölçmek amaçlanmıştır. "Türk Gıda Kodeksi Gıda Etiketleme ve Tüketicileri Bilgilendirme Yönetmeliğ̈i", gıda hakkında bilgilendirme açısından tüketicilerin üst düzeyde korunmasına ilişkin kuralları belirlemektedir. Gıda okuryazarlı̆̆ını tespit etmek amacıyla, yönetmeliğe göre Türkiye'de satılan paketli gıdalarda belirtilmesi gereken zorunlu bilgiler kullanılarak doğru / yanlışşseklinde sorular içeren soru formu oluşturulmuştur. Gıda etiketi okuryazarlık seviyelerinin tespiti için 15-29 yaş aralı̆̆ında yer alan 348 genç tüketiciden elde edilen cevaplar kullanılmıştır. Elde edilen cevaplara göre genç tüketicilerin en çok katkı maddelerine $(\% 60,6)$ önem verdikleri fakat bu konudaki gıda okuryazarlik seviyelerinin düşük olduğu $(\% 32,2)$ ortaya çıkmıştır. Vitaminler $(\% 64,4)$, trans yağlar $(\% 77,9)$ gibi reklamlarda sıklıkla vurgulanan gıda içerikleri hakkında ise okuryazarlık seviyelerinin yüksek olduğu tespit edilmiştir. Geleceğin sağlıklı nesillerinin oluşturulması için gençlerde gıda etiketi okuryazarliğı seviyesinin yükseltilmesi gereklidir. Bu amaçla ilkokuldan başlayarak eğitim sisteminin her kademesinde bu konuda eğitimlerin düzenlenmesinde fayda görülmektedir. İşletmelerin pazarlama faaliyetlerinden olan ürün tanıtımlarında, reklamlarında, ürün ambalajlarında; sağhlklı gıdaya ve beslenmeye dair içeriklere daha fazla yer vermesinde yarar görülmektedir. Böylelikle sağlıkl gida tüketimine yönelik talep artacak, dolayısıyla da geleceğin să̆lıklı toplumları oluşturulabilecektir.

$\begin{array}{llll}\text { Keywords: } & \text { Food Label } & \text { Food Label Literacy } & \text { Young Consumer } \\ \text { JEL Codes: } & \text { M38 } & \text { M39 } & \text { Q18 }\end{array}$

* 4-6 Eylül 2019 tarihinde İzmir' de düzenlenen II. Business \& Organization Research (BOR) Conference' da sunulan özet bildirinin gözden geçirilmiş ve geliştirilmiş halidir.

${ }^{1}$ Doç. Dr., Muğla Sitkı Koçman Üniversitesi, ykizgin@mu.edu.tr,

${ }^{2}$ Dr. Öğr. Üyesi, Muğla Sıtkı Koçman Üniversitesi, btuncer@mu.edu.tr,

https://orcid.org/0000-0002-7844-052X https://orcid.org/0000-0003-0822-6832 


\section{EXTENDED ABSTRACT}

\section{DETERMINATION OF FOOD LABEL LITERACY ACCORDING TO TURKISH FOOD CODEX: A RESEARCH ON YOUNG CONSUMERS}

\section{LITERATURE}

It is possible for a country to be economically and socially powerful and wealthy, with individuals in the country being healthy. The most important condition for reaching such a social structure; society has a healthy food consumption and a conscious understanding of nutrition.

\subsection{RESEARCH SUBJECT}

Food literate individuals, food, nutrients, food groups, nutrition, nutritional diseases etc. know the meaning of the terms related to food and nutrition terminology, and interpret the messages in images such as food labels, food plate, food pyramid correctly (Aktaş and Özdoğan, 2016:149). Miller and Cassady (2015) state that individuals with food literacy can choose healthier foods by getting help from food labels. Parmenter and Wardle (1999) state that it is possible to reach more clear and confusing information in getting rid of the complexity of food literacy and dieting. Drichoutis, Lazaridis and Nayga (2006) state that consumers receive support from the food label to avoid negative foods in packaged food products, thus affecting their buying behavior. Ronto, Ball, Pendergast and Harris (2016) found that in their studies, young people attach importance to food safety and hygiene, and if they have the right information, it will be easier for them to make a healthy food choice.

\subsection{RESEARCH PURPOSE AND IMPORTANCE}

The importance of proper nutrition is obvious for building healthy communities in the future. The aim of this study is to measure the food label literacy of young people who will become adults of the future, especially in light of the fact that packaged foods have an important place in today's food consumption.

\subsection{CONTRIBUTION of the ARTICLE to the LITERATURE}

According to the Turkish Food Codex Food Labeling and Consumer Information Regulation, the information contained in packaged food labels will contribute to creating a healthy food purchase choice by understanding and interpreting them correctly. It is thought that the study carried out to draw attention to the level of food literacy will be useful in developing a functional scale in this area. The lack of a functional question form developed on the measurement of "food and nutrition literacy" in both the International and national literature makes the question form sought in this study more meaningful and useful, as well as it is thought that it will be useful to reach a healthier society by opening the subject to academic debate.

\section{DESIGN AND METHOD}

In this study, a questionnaire was prepared to determine the level of food label literacy based on the Turkish Food Codex Food Labeling and Consumer Information Regulation.

\subsection{RESEARCH TYPE}

This research is a descriptive study for its purpose. Based on the data obtained with the questionnaire; it is aimed to understand the food literacy levels of young participants and to obtain descriptive data that can shed light on other "food literacy" studies in this field.

\subsection{DATA COLLECTION METHOD}

In the Turkish Food Codex Food Labeling and Consumer Information Regulation, the provisions that should be included in the food product labels are taken into consideration. Young consumers' understanding of nutritional values on food product labels; it was tried to be determined with the help of 348 data collected between the dates of 01.05.2019 - 30.05.2019 over a sample determined through easy sampling throughout Muğla province. Since the data used in the study was collected before 01.01.2020, an ethics committee permit document is not required. The participants of the study were selected from individuals aged between 15-29. The questionnaire used consists of 2 parts. In the first 
part, questions were asked to measure the demographic characteristics of the participants. In the second part, there are questions created to determine the comprehensibility of the food information that should be written on the packaged food products within the scope of the Turkish Food Codex Food Labeling and Consumers Information Regulation.

\subsection{QUANTITATIVE/QUALITATIVE ANALYSIS}

"Food and nutrition literacy" levels of consumers were tried to be understood in order to provide correct/incorrect answers about certain information provided to them with the help of an expert on food and nutrition.

\section{FINDINGS AND DISCUSSION}

$52.5 \%$ of the participants are women, $47.7 \%$ are men, $75.3 \%$ continue their education life, $82.8 \%$ have high school and university level education, and $40.5 \%$ age distribution. $15-19,31.9 \%$ of them are between the ages of $20-24$ and $27.6 \%$ of them are between the ages of $25-29$. It is seen that the most noticeable label information is $60.6 \%$ contributions. This is followed by calories $(17.0 \%)$ and fats $(7.8 \%)$, respectively. It is seen that the participants have an average of $50.7 \%$ correct and $49.3 \%$ incorrect information in energy related question groups. Participants had the correct knowledge that walnuts are a good energy source $(77.9 \%)$; it is seen that they do not have enough information about the amount of calories to be taken $(31.6 \%)$, cocoa $(45.7 \%)$ and coffee $(47.7 \%)$. When the answers to the questions about the oils were examined, it was determined that the participants had an average of $55.3 \%$ correct and $44.7 \%$ wrong information. It was concluded that the participants were knowledgeable about the harms of trans fatty acids $(77.9 \%)$, the butter in saturated fats being least harmful than others $(64.9 \%)$, and generally avoiding fats. However, it was found that they did not know that unsaturated fats were accepted as good fats (68.1\%) and saw red meat directly as a bad source of cholesterol (58.9\%). According to the answers given by the participants to the questions regarding carbohydrate / sugar, it was discovered that they had $54.5 \%$ correct and $45.5 \%$ false information. It was observed that they had a high level of knowledge about carbohydrates $(68.4 \%)$ and that they had $85.9 \%$ wrong information, especially that brown sugar was healthier than white sugar. When questions about proteins are examined, $65.8 \%$ of participants have accurate information. It was revealed that the benefits of meat, fish, eggs and milk in terms of protein are well known (93.4\%) and that vegetables are a source of protein $(66.1 \%)$ are not well known. When the questions about salt are examined, it is seen that the rate of having correct information among the participants remains at $47.1 \%$. It is observed that $90.8 \%$ of the daily salt consumption should not exceed 10 grams in particular. It was revealed that the participants knew that the expression of sodium chloride in the food labels means salt, by $73.9 \%$. It was determined that the participants had the correct knowledge of $66.4 \%$ about vitamins. It can be said that awareness about $C$ and $B$ vitamins $(69 \%)$ is high. It is seen that the participants have $63 \%$ correct information on fiber related questions. It is seen that the contribution of fiber foods to feel fullness $(67.2 \%)$ and to the digestive system $(67.2 \%)$ is known, and the contribution of fiber foods to regulate blood cholesterol and blood sugar is not known enough (47.1\%).

\subsection{FINDINGS as a RESULT of ANALYSIS}

The fact that young consumers pay attention to the labels of packaged foods that they buy most shows that they have a high level of awareness in this regard.

\subsection{DISCUSSING the FINDINGS with the LITERATURE}

Although $60.6 \%$ of the participants are the additives of the information they pay most attention to, the $67.8 \%$ of the questions about the additives are incorrect. It is especially suggestive that $88.5 \%$ of respondents who have a misconception that foodstuffs starting with the Code" E " are harmful to human health. However, the fact that $\mathrm{E}$ code is given to an additive also means that it is found safe by the European Union and the European Federation of Food Additives and Food Enzymes (Winter, 2009: 106). The aim is to inform consumers by classifying additives.

\section{CONCLUSION, RECOMMENDATION AND LIMITATIONS}

It is clear that according to the Turkish Food Codex Food Labeling and Consumer Information Regulation, the correct understanding and interpretation of the information contained in the packaged food labels will contribute to creating a healthy food purchase preference. 


\subsection{RESULTS of the ARTICLE}

It is useful to position the necessary efforts to gain food label literacy skills within the education system. With the development of the idea of healthy eating, the producers of packaged food in addition to the legal obligation to provide information to be educational to consumers will increase the preferability of their products. It can be expected that the improvements to be achieved in holistic terms will also contribute positively to the purchasing processes of consumers and will lead to Planned purchasing behavior.

\subsection{SUGGESTIONS BASED on RESULTS}

In future studies; beside some demographic, socio-economic group variables of consumers' reading / not reading labels; specialization can be provided by associating with some social theories such as planned purchasing theory. On the other hand, it is thought that carrying out studies to examine the conditions of those who show food label reading behavior and those who do not, will help to understand the importance of food literacy in terms of health.

\subsection{LIMITATIONS of the ARTICLE}

As the aim of the study was to determine the level of literacy, no further analysis was provided. In later studies, more comprehensive analyses will be able to be adhered to by investigating the effect of literacy level on consumer purchasing processes. 


\section{GİRIŞ}

Bir ülkenin ekonomik ve sosyal açıdan güçlü ve zengin olabilmesi; ülkedeki bireylerin sağlıklı olması ile mümkündür. Böylesi bir toplumsal yapıya ulaşmanın en önemli koşulu; toplumun sağlıklı gıda tüketim ve bilinçli bir beslenme anlayışına sahip olmasıdır. Tüm dünyada, bu konuda ülke yönetimlerinin alacağı üretim ve tüketim yönlü düzenleyici tedbirlere her geçen gün daha fazla ihtiyaç bulunmaktadır. Bu sayede sağlıklı gıda ürünlerini üreterek; toplumsal anlamda sağlıklı gıda tüketimi ve sağlıklı beslenme alışkanlıklarının kazandırılması ve sağlıklı toplumların oluşturulması mümkün olabilecektir. Ancak bunun için öncelikle, sağlıklı gıda tüketimi ve sağlıklı beslenme konusunda tüketici davranışlarının belirlenmesi ve anlaşılması gerekir.

TUIK 2019 verilerine göre, 15-29 yaş arası nüfus 19,32 milyon olup toplam nüfusun \%23,23'ünü oluşturmaktadır. Genç nüfusun \%6,6'sı belde ve köylerde, $\% 93,4^{\prime}$ ü il ve ilçe merkezlerinde yaşamaktadır. 2007 yılında ise 15-29 yaş arası genç nüfusun \%72,33'ü il ve ilçe merkezlerinde yaşadığı göz önüne alındığında; nüfusun artışı ve özellikle genç nüfusun kırsaldan şehre taşınmasındaki artış; kentleşme oranına bağlı olarak kentteki üretim ve tüketim dengesinin bozulmasına sebep olmaktadır (Yılmaz, 2019:120). Kentleşme ile birlikte insanların yaşam tarzlarındaki hızlı değişimler, tarım ve hayvancılıktaki değişimlere yol açarak bireylerin tüketim alışkanlıklarının da değişmesine neden olmaktadır. Bu kentleşmeye bağlı olarak gıda tüketim alışkanlıkları içinde bulunulan yeni koşullarına uyum sağlamaktadır. Özellikle hızlı tüketilebilen işlenmiş gıda tüketiminin artması ile birlikte ABD, Kanada gibi gelişmiş ülkelerde gençler arasında obezite sorunu çok önemli sağlık, ekonomik ve toplumsal sorun haline gelmiştir (Slater, Falkenberg, Rutherford ve Colatruglio, 2018:548).

Çocukların ve gençlerin sağlıksız beslenmesi, gelecekte fiziksel ve zihinsel sağlık problemi yaşama risklerini arttırmaktadır (Slater vd.,2018:549). Sağlıklı yaşıtlarına göre, aşırı kilolu ve obez olan gençlerin ortalama yaşam kaliteleri düşmekte, özgüven eksikliğine bağlı depresyon sonucu toplumdan dışlanmakta ve bunlara bağlı olarak daha düşük yaşam başarısı, kontrol edilemez boyutlara ulaşan 
sosyal güvenlik harcamaları ve düşük ekonomik verimlilik gibi bazı toplumsal sorunları doğurmaktadır (Lobstein vd.,2015:2).

Özellikle Türkiye gibi gelişmekte olan ve genç nüfusun fazla olduğu ülkelerde geleceğin sağlıklı toplumunu oluşturabilmenin en önemli temel taşı sağlıklı g1da ve sağlıklı beslenebilen bireyleri yetiştirebilmektir. Bu açıdan gıda okuryazarlığı konusu ülkemizin geleceğinin sağlıklı bir toplumsal yapıya ulaştırılmasında önemli bir araç olarak görülmelidir. Bu konuda önceliğin geleceğin yetişkinleri olacak çocuklara ve gençlere verilmesi gereklidir.

Toplumsal anlamda sağlıklı gıda ve beslenme anlayışının yerleştirilmesinde kullanılabilecek en önemli araçlardan birisi de gida paketlerinde yer alan ürün etiketleridir. Ürünün verdiği sözü ve sağladığı yararı gösteren ürün etiketleri vasıtasıyla tüketiciler; ürün bileşimi, fiyatı, son kullanma tarihi, kullanım süresi, üretim yeri ve besleyicilik değerleri hakkında bilgiler elde ederken; tüketici güveni elde etmenin yanı sıra, ürün kullanılabilirliği ve ihtiyaçların tatmin düzeyi ile ilgili satın alma karar süreçlerine de etki edebilmektedir.

Gıda hakkında bilgilendirme amaçlı etiket ilk defa 1940 yılında diyet amaçlı satılan ürünlerin etiketlerinde $\mathrm{ABD}^{\prime}$ de kullanılmaya başlanmıştır (Lewis, 2019: 4). Dünya Sağlık Örgütü (WHO) ile Birleşmiş Milletler Gıda ve Tarım Örgütü (FAO) tarafından 1973 yılındaki düzenlenen toplantıda ise gida etiketlerindeki bilgilendirmelerin daha anlaşılır olması amacıyla tüketicilerin de eğitilmesi gerektiği konusu tartışılmıştır ve bu konudaki ilk kodeks 1985 yılında yayınlanmıştır (Lewis, 2019: 18). Dünya Sağlık Örgütü (WHO) ile Birleşmiş Milletler Gıda ve Tarım Örgütü (FAO)'nün yayınlamış olduğu 2020-2025 kodeks stratejik planında; her yaşta sağlıklı yaşamı sağlamak için, gıda etiketlerinde yer alan standartların geliştirilerek daha bilinçlendirici olması gerektiği belirtilmektedir (http://www.fao.org/3/ca5645en/CA5645EN.pdf).

Ancak etiketler üzerindeki bilgilerin azlığı, karmaşık oluşu veya çelişkili olması yanında tüketicilerin bu etiket bilgilerini kullanma alışkanlığının olmaması ve/veya anlama becerilerinden yoksun olunması gibi nedenlerle de ürün kalitesinin doğru değerlendirilemeyerek satın alma kararının olumsuz etkilenmesi; bu sayede sağlıklı 
g1da seçiminde ürün etiketinden beklenen faydanın elde edilememesi durumuyla karşılaşılabilmektedir. Bu nedenle tüketicilerin sağlıklı g1da ürün seçimlerini kolaylaştıracak, gıda etiketlerinin ürünle birlikte okunulabilir ve anlaşılabilir halde verilmesi yanında; tüketicilerin gıda ürün etiketlerini okuma alışkanlıklarının ve becerilerinin olması ve geliştirilmesi gereklidir. $\mathrm{Bu}$ ise tüketicilerin "gıda etiketi üzerindeki gıda ve beslenme bilgilerini anlayabilme, değerlendirme becerileri" şeklinde tanımlanan" gıda okuryazarlık" seviyelerinin anlaşılmasını gerektirmektedir.

$\mathrm{Bu}$ çalışma ile geleceğin yetişkinleri olacak gençlerin gıda etiketi okuryazarlık düzeylerinin belirlenmesi ve bu konuya olan toplumsal ilginin artırılması amaçlanmaktadır.

\section{LITERATÜR TARAMASI}

Gıda okuryazarlığı ile ilgili literatürde, g1danın kendisine gida okuryazarlığından daha fazla önem verildiği görülmektedir. Gıda okuryazarlığı, insanların kendileri ve aileleri için sağlıklı, lezzetli, uygun maliyetli yemekleri hazırlamalarına yardımcı olan bir dizi beceri ve özelliği barındırmaktadır. İşlenmiş gıda üretimi ve tüketiminin artışılla beraber gıda okuryazarı olmak, bireylere gıdanın içeriklerini daha iyi kavrama ve gıdadan kaynaklı olumsuzluklardan korunma imkânı da sağlamaktadır. Paketli gıdaların etiketlerinde yer alan bilgilerin anlaşılması ve o bilgilerin beslenme alışkanlıklarımızın şekillenmesinde kullanılması, daha sağlıklı olmamıza yardımcı olacaktır.

Tüketicilerin "g1da etiketi üzerindeki g1da ve beslenme bilgilerini anlayabilme, değerlendirme becerileri" şeklinde tanımlanan" g1da okuryazarlık" seviyelerinin öncelikle anlaşılması gereklidir. Gıda etiketi okumaya yönelik literatürün; besin değerlerini anlamlandırma, gıda etiketlerinin önemi, demografik faktörlere göre gıda okuryazarı olup olmamaya yönelik çalışmalara odaklandığı görülmektedir. Bu konuda yapılan çalışmalar gıda okuryazarlığının sonuçlarına daha çok odaklanıldığını göstermektedir.

Gıda okuryazarı bireyler, besin, besin öğesi, besin grupları, beslenme, beslenme ile ilişkili hastalıklar vb. gıda ve beslenme terminolojisi ile ilişkili terimlerin 
anlamlarını bilir, besin etiketleri, besin tabağı, besin piramidi gibi görsellerdeki mesajları doğru bir şekilde yorumlayabilirler (Aktaş ve Özdoğan, 2016:149). Bireyler gıda okuryazarı olduğu zaman besinler, beslenmeye bağlı yaşanabilecek olumlu ve olumsuz durumlar hakkında bilgi sahibidirler. Aynı zamanda ürün reklamlarında yer alan g1da besin değerleri hakkında da bilgi sahibidirler (Vidgen ve Gallegos, 2012:46).

Miller ve Cassady (2015), g1da okuryazarlığına sahip bireylerin, gıda etiketlerinden yardım alarak daha sağlıklı besinler seçebildiklerini belirtmektedirler. Çalışmalarında, özellikle yaşın ilerlemesiyle beraber gıda okuryazarlığı seviyesi artıkça, bireylerin bilinçaltlarında biriktirdikleri bilgilerin gıda etiketi okumada etkili olduğunu ve karar verme sürecine katkıda bulunduğunu ortaya koymaktadırlar.

Post, Mainous, Diaz, Matheson ve Everett (2010), şeker ve hipertansiyon gibi kronik hastalıkları bulunan orta yaş üstü bireyler ile yaptıkları araştırmalarında gıda etiketlerinin önemine değinmiş, kadınların gıda okuryazarlığının erkeklere göre daha fazla olduğunu tespit etmişlerdir.

Parmenter ve Wardle (1999), gida okuryazarlı̆̆ı ile diyet yapmanın karmaşıklığından kurtulmada daha açık, kafa karıştırmayan bilgilere ulaşmaya imkân sağlandığını ifade etmektedirler. Drichoutis, Lazaridis ve Nayga (2006), tüketicilerin paketli gıda ürünlerindeki olumsuz besinlerden kaçınmak için gıda etiketinden destek aldıklarını, böylelikle satın alma davranışlarının etkilendiğini belirtmektedirler. Gıda etiketlerinin; tüketicileri eğitmek için bir bilgilendirme kampanyası ile birleştirilmesi durumunda, gıda okuryazarlığının ürün değeri ve algıları üzerinde olumlu etki yaratarak satın alma davranışını etkilediğini ifade etmektedirler (Drichoutis vd., 2006:14)

Dickson-Spillmann, Siegrist ve Keller. (2011), İsviçreli tüketiciler ile yaptıkları çalışmalarında; tüketicilerin gıda okuryazarlığı bilincinin yeterli olmadığını ortaya çıkartmışlardır. Tüketicilerin \%40'ının, meyve sebzelerin vücuda vitamin ve mineral takviyesi sağladığını, diğer faydalarının farkında olmadıklarını tespit etmişlerdir. Tüketicilerin balık yağı ile kırmızı etin yağının farklarından, hatta etin yağlı ve yağsız tarafının farkından bile haberdar olmadıklarını bu sebeple sağlıklı beslenme 
duyarlılığının kazanılması için beslenme eğitimlerinin önemli olduğunu ifade etmişlerdir.

Wardle, Parmenter ve Waller. (2000), g1da okuryazarlığ tüketimi arasında meslekten ve eğitim seviyesinden bağımsız olarak güçlü bir ilişki tespit etmiştir. Azman ve Sahak (2014), etiketteki gıda bilgilerinin orta ve üstü yaştakiler ile eğitim seviyesi yüksek olan bireylerde satın alma davranışında etkili olduğunu belirtmektedirler. Grunert, Wills ve Fernández-Celemín (2010), gençlerde ve sosyal olarak üst tabakada olan bireylerde eğitimin ve entelektüel birikimin etkisiyle gıda okuryazarlığının yüksek olduğunu tespit etmişlerdir. Ronto, Ball, Pendergast ve Harris (2016), yaptıkları çalışmalarında gençlerin gıda güvenliği ve hijyeni konusuna önem verdiklerini, doğru bilgilere sahip olmaları durumunda sağlıklı gıda tercihi yapmalarının kolaylaşacağını tespit etmişlerdir.

Bu bağlamda gıda okuryazarlığının gıda etiketlerinin anlaşılır hale gelmesinde de etkisi aşikardır. Gıda etiketi okuma ve okuduğunu anlama becerilerinin kazandırılması ve bu becerilerin sağlıklı beslenme davranışına dönüştürülmesi önem kazanmaktadir.

\section{ARAŞTIRMA YÖNTEMI}

$\mathrm{Bu}$ araştırma, amacı açısından tanımlayıcı düzeyde bir çalışmadır. $\mathrm{Bu}$ çalışmada, Türk Gıda Kodeksi Gıda Etiketleme ve Tüketicileri Bilgilendirme Yönetmeliği'nden hareketle g1da etiketi okuryazarlık seviyesini belirlemeye yönelik bir soru formu hazırlanmıştır. Bu soru formu ile elde edilen verilerden hareketle; genç katılımcıların gıda okuryazarlık düzeylerinin anlaşılması ve buna bağlı olarak bu alanda yapılacak olan diğer "gıda okuryazarlık" çalışmalarına 1şık tutabilecek tanımlayıcı düzeyde verilerin elde edilmesi amaçlanmıştır.

Bu amaçla Türk Gıda Kodeksi Gıda Etiketleme ve Tüketicileri Bilgilendirme Yönetmeliğinde gıda ürün etiketlerinde yer alması gereken hükümler dikkate alınarak, genç tüketicilerin gıda ürün etiketlerindeki beslenme değerlerini anlayabilme düzeyleri; Muğla ili genelinde kolayda örnekleme yolu ile belirlenmiş bir örneklem üzerinden, 01.05.2019 - 30.05.2019 tarihleri arasında toplanan 348 adet veri 
yardımıyla belirlenmeye çalışılmıştır. Çalışmada kullanılan veriler 01.01.2020 tarihinden önce toplanmış olduğu için etik kurul izin belgesi gerekmemektedir.

Araştırmanın katılımcıları 15-29 yaş arası bireylerden seçilmiştir. Kullanılan soru formu 2 bölümden oluşmaktadır. Birinci bölümde katılımcıların demografik özelliklerini ölçmeye yönelik sorular sorulmuştur. İkinci bölümde ise katılımcıların Türk Gıda Kodeksi Gıda Etiketleme ve Tüketicileri Bilgilendirme Yönetmeliği kapsamında paketli g1da ürünleri üzerinde yazılması gereken g1da bilgilerinin tüketiciler tarafından anlaşılabilirliğinin belirlenmesi amacıyla oluşturulan sorular yer almaktadir.

Gıda ve beslenme konusunda bir uzman kişiden yardım alınarak kendilerine sunulan bazı bilgiler hakkındaki verdikleri doğru/yanlış şeklindeki cevaplar ölçüsünde tüketicilerin "gıda ve beslenme okuryazarlık" düzeyleri anlaşılmaya çalışılmıştır. Hem uluslararası hem de ulusal yazında "gıda ve beslenme okuryazarlığı" ölçümü konusunda geliştirilmiş işlevsel bir soru formu olmaması, bu çalışmada ortaya konulmaya çalışılan soru formunu daha anlamlı ve kullanışlı yapmasının yanında konunun akademik olarak tartışmaya açılarak daha sağlıklı bir topluma ulaşılmasında yararlı olacağı düşünülmektedir.

\section{ANALIZ VE BULGULAR}

Tablo 1 araştırmaya katılanlara ait demografik özellikler yer almaktadır.

Tablo 1. Katılımcıların Demografik Özellikleri

\begin{tabular}{|lrrlrr|}
\hline Cinsiyet & Kişi (n) & Yüzde (\%) & Eğitim & Kiși (n) & Yüzde (\%) \\
\hline Kadın & 182 & 52.3 & İk-orta öğretim & 43 & 12.4 \\
Erkek & 166 & 47.7 & Lise ve dengi & 145 & 41.7 \\
Toplam & 348 & 100.0 & Üniversite & 143 & 41.1 \\
& & & Lisansüstü & 17 & 4.9 \\
& & & Toplam & 348 & 100.0 \\
& & & & & \\
Yaș & & & Okul Durumu & & \\
$15-19$ & 141 & 40.5 & & & \\
$20-24$ & 111 & 31.9 & Öğrenci & 262 & 75.3 \\
$25-29$ & 96 & 27.6 & Öğrenci değil & 86 & 24.7 \\
Toplam & 348 & 100.0 & Toplam & 348 & 100.0 \\
\hline
\end{tabular}

Tablo 1 incelediğinde; katılımcıların \%52,3'ünün kadın, \%47,7'sinin erkek olduğu, \%75,3'ünün eğitim hayatına devam ettiği, \%82,8'inin lise ve üniversite 
düzeyinde eğitime sahip olduğu, yaş dağllımlarının da \%40,5'inin 15-19, \%31,9' unun 20-24, \%27,6' sının da 25-29 yaş aralığında olduğu görülmektedir. Çalışmanın da amacı olduğu üzere gençler üzerinde araştırma yapılmış olup, 15-19 yaş arasının lise düzeyinde, 20-24 arasının üniversite düzeyinde eğitim aldığı̆, 25 yaş ve üzerindekilerin de lisansüstü eğitim alan ya da iş hayatına atılmaya hazır olan ya da atılmış bulunan genç yetişkinler olduğu varsayılmaktadır. Tablo 2'te araştırmaya katılanların en çok dikkat ettikleri etiket bilgileri yer almaktadır.

Tablo 2. En Çok Dikkat Edilen Etiket Bilgisi

\begin{tabular}{|l|r|r|}
\hline En Çok Dikkat Edilen Etiket Bilgisi & Kiși (n) & Yüzde (\%) \\
\hline Katkılar & 209 & 60.8 \\
\hline Kalori & 59 & 17.2 \\
\hline Yağlar & 27 & 7.8 \\
\hline Dönüştürülmüş yağlar & 11 & 3.2 \\
\hline Şeker & 14 & 4.1 \\
\hline Karbonhidratlar & 4 & 1.2 \\
\hline Proteinler & 4 & 1.2 \\
\hline Tuz & 1 & 0.1 \\
\hline Diğer & 15 & 4.4 \\
\hline Toplam & $\mathbf{3 4 4}$ & $\mathbf{1 0 0 . 0}$ \\
\hline
\end{tabular}

Gıda etiketleri incelenirken en çok dikkat edilen etiket bilgisinin \%60,6 oranında katkılar olduğu görülmektedir. Bunu sırasıyla kalorinin $(\% 17,0)$ ve yağların $(\% 7,8)$ takip ettiği görülmektedir. Genç tüketicilerin satın aldıkları paketli gıdaların etiketlerinde en çok dikkat ettikleri bilginin katkı maddeleri olması bu konuda bilinç düzeylerinin yüksek olduğunu göstermektedir.

Paketli g1da etiketleri üzerinde bulunması zorunlu olan; enerji, yă̆, karbonhidrat/şeker, protein, tuz, vitamin, lif, katkı maddelerine ilişkin bilgiler hakkında katılımcıların bilgi düzeylerini öğrenmek amacıyla her bir bilgi grubu hakkında doğru / yanlış şeklinde ifadelerin yer aldığı önermeler sorulmuş ve alınan cevaplara istinaden katılımcıların g1da okuryazarlığı seviyesi ortaya konulmaya çalışılmıştır. Elde edilen sonuçlar Tablo 3' de yer almaktadır. 
Tablo 3. Katılımcıların Gıda Etiketi Okuma Düzeyleri

\begin{tabular}{|c|c|c|c|c|c|c|c|c|c|}
\hline \multirow{2}{*}{ Enerji Île İlgili Sorular } & \multicolumn{2}{|c|}{ Doğru } & \multicolumn{2}{|c|}{ Yanlıs } & \multirow{2}{*}{ Yağlarla İle İlgili Sorular } & \multicolumn{2}{|c|}{ Doğru } & \multicolumn{2}{|c|}{ Yanlus } \\
\hline & $\mathrm{N}$ & $\%$ & $\mathrm{~N}$ & $\%$ & & $\mathbf{N}$ & $\%$ & $\mathbf{N}$ & $\%$ \\
\hline $\begin{array}{l}\text { Günlük alnmmas1 gereken ortalama } \\
\text { kalori miktarı } 2000^{\prime} \text { dir. }\end{array}$ & 110 & 31,6 & 238 & 68,4 & $\begin{array}{l}\text { Doymamıš yağlar sağlıkh, iyi yağlar } \\
\text { olarak kabul edilir }\end{array}$ & 111 & 31,9 & 237 & 68,1 \\
\hline $\begin{array}{l}\text { Kakao oramı yüksek çikolatalar, } \\
\text { enerji kaynağı açısından iyidir. }\end{array}$ & 159 & 45,7 & 189 & 54,3 & $\begin{array}{l}\text { Doymuş yağlar arasında en iyi olan } \\
\text { yağ, tereyağıdır }\end{array}$ & 226 & 64,9 & 122 & 35,1 \\
\hline $\begin{array}{l}\text { Omega } 3 \text { açısından en zengin } \\
\text { kuruyemiş ceviz, mükemmel bir } \\
\text { enerji kaynağıdır. }\end{array}$ & 271 & 77,9 & 77 & 22,1 & $\begin{array}{l}\text { Yağlar, enerji kaynağı olmalarmm yanı } \\
\text { sıra, yağda çözünen vitaminlerin } \\
\text { vūcuda emilimini sağlarlar. }\end{array}$ & 193 & 55,5 & 155 & 44,5 \\
\hline Kahve iyi enerji veren bir içeceltir. & 166 & 47,7 & 182 & 52,3 & $\begin{array}{l}\text { Trans yağ asitleri içeren yağlarm belirli } \\
\text { ölçülerin üzerinde tüketilmesi sağlık } \\
\text { açısından risk taşır. }\end{array}$ & 271 & 77,9 & 77 & 22,1 \\
\hline Genel Ortalama (\%) & 50 & ,7 & & 9,3 & $\begin{array}{l}\text { Yağ her zaman sağhlğınız için kōtüdür, } \\
\text { bu nedenle mümkün olduğunca } \\
\text { kaçınmalısız. }\end{array}$ & 210 & 60,3 & 138 & 39,7 \\
\hline $\begin{array}{l}\text { Karbonhidrat/Șeker İle İlgili } \\
\text { Sorular }\end{array}$ & & & & & $\begin{array}{l}\text { Kırmızı et, kötü kolesterole neden olan } \\
\text { yağ balamindan zengin bir besindir. }\end{array}$ & 143 & 41,1 & 205 & 58,9 \\
\hline $\begin{array}{l}\text { Karbonhidratlar kan ģekerini } \\
\text { yükseltir. }\end{array}$ & 220 & 63,2 & 128 & 36,8 & Genel Ortalama (\%) & 58 & ; 3 & & 7 \\
\hline $\begin{array}{l}\text { Karbonhidrat yeterli miktarda } \\
\text { alındığında kilo aldırmaz aksine; } \\
\text { vūcudun dengeli ve sağlıklı biçimde } \\
\text { çalığmasım sağlar. }\end{array}$ & 238 & 68,4 & 110 & 31,6 & Proteinlerle İle İgili Sorular & & & & \\
\hline $\begin{array}{l}\text { Beyaz geker ve bal basit } \\
\text { karbonhidratlardandrr. }\end{array}$ & 126 & 36,2 & 222 & 63,8 & $\begin{array}{l}\text { Et, ballk, yumurta ve sūt, kaslarda } \\
\text { protein sentezi için gerekli olan kaliteli } \\
\text { protein kaynaklandur. }\end{array}$ & 325 & 93,4 & 23 & 6,6 \\
\hline $\begin{array}{l}\text { Esmer şeker beyaz șekerden çok } \\
\text { daha sağllklıdır. }\end{array}$ & 49 & 14,1 & 299 & 85,9 & $\begin{array}{l}\text { baklagiller, kabuklu yemiš ve yağll } \\
\text { tohumlar protein içeren besinlerdendir. }\end{array}$ & 244 & 70,1 & 104 & 29,9 \\
\hline Genel Ortalama (\%) & 45 & 5 & $\mathbf{5}$ & 1,5 & Sebzelerin protein oram çok dūşülktür & 118 & 33,9 & 230 & 66,1 \\
\hline Tuz Île İlgili Sorular & & & & & Genel Ortalama (\%) & 65 & ;8 & & 2 \\
\hline $\begin{array}{l}\text { Tuzun vücut sivı dengesinin } \\
\text { ayarlanmasında, kas ve sinir } \\
\text { fonksiyonlarnnda önemli görevleri } \\
\text { vardır. }\end{array}$ & 203 & 58,3 & 145 & 41,7 & Vitaminlerle İle İlgili Sorular & & & & \\
\hline $\begin{array}{l}\text { Tuzun kimyasal adi sodyum } \\
\text { klorürdür. }\end{array}$ & 257 & 73,9 & 91 & 26,1 & $\begin{array}{l}\mathrm{C} \text { ve B vitaminleri her gün düzenli } \\
\text { olarak alımmas gerekir. }\end{array}$ & 240 & 69,0 & 108 & 31,0 \\
\hline $\begin{array}{l}\text { Günlük tuz tüketimi } 10 \text { gr. } \\
\text { geçmemelidir. }\end{array}$ & 32 & 9,2 & 316 & 90,8 & $\begin{array}{l}\mathrm{A}, \mathrm{D}, \mathrm{E} \text { ve } \mathrm{K} \text { vitaminleri insan } \\
\text { vūcudunda depo edilir. }\end{array}$ & 208 & 59,8 & 140 & 40,2 \\
\hline Genel Ortalama (\%) & 47 & 1 & 5 & :9 & Genel Ortalama (\%) & 64 & 1,4 & & 6 \\
\hline Liflerle İle İlgili Sorular & & & & & Katkı Maddeleriyle İlgili Sorular & & & & \\
\hline $\begin{array}{l}\text { Lifli gıdalar, insan sindirim } \\
\text { sisteminin sağlıkl çalığması için } \\
\text { gereklidir. }\end{array}$ & 260 & 74,7 & 88 & 25,3 & $\begin{array}{l}\text { Katkasız ibareli ürünlerde koruyucu, } \\
\text { renklendirici, tatlandırıc1, vb ilave } \\
\text { bulummamaktadır. }\end{array}$ & 184 & 52,9 & 164 & 47,1 \\
\hline $\begin{array}{l}\text { Lifli gıdalar daha çok yer kaplayıp } \\
\text { daha çok tokluk hissi verirler. }\end{array}$ & 234 & 67,2 & 114 & 32,8 & $\begin{array}{l}\text { E kodu ile başlayan gıda maddeleri } \\
\text { insan sağhlğına zararlıdır. }\end{array}$ & 40 & 11,5 & 308 & 88,5 \\
\hline $\begin{array}{l}\text { Lifler, kolesterol ve kan şekerini } \\
\text { dengeler. }\end{array}$ & 164 & 47,1 & 184 & 52,9 & Genel Ortalama (\%) & 32 &, 2 & & ,8 \\
\hline Genel Ortalama (\%) & 63 & 0 & 9 & 7,0 & & & & & \\
\hline
\end{tabular}

Tablo 3 incelendiği zaman katılımcıların enerji ile ilgili soru gruplarında ortalama \%50,7 doğru, \%49,3 oranında yanlış bilgiye sahip oldukları görülmektedir. Katılımcıların, cevizin iyi bir enerji kaynağı olması konusunda $(\% 77,9)$ doğru bilgiye sahip oldukları; günlük alınması gereken kalori miktarı $(\% 31,6)$, kakao $(\% 45,7)$ ve 
kahvenin $(\% 47,7)$ iyi enerji verdiği konusunda yeterli bilgiye sahip olmadıkları görülmektedir.

Yağlarla ilgili sorulara verilen cevaplara bakıldığı zaman, katılımcıların ortalama \%55,3 doğru, \%44,7oranında ise yanlış bilgiye sahip oldukları belirlenmiştir. Katılımcıların trans yă̆ asitlerinin zararları $(\% 77,9)$, doymuş yağlar içerinde yer alan tereyağının diğerlerine göre en az zararlı olması (\%64,9), genel anlamda yağlardan uzak durulması konularında bilgili oldukları sonucu ortaya çıkmıştır. Ancak doymamış yağların iyi yağ olarak kabul edildiğini bilmedikleri $(\% 68,1)$ ve kırmızı eti direkt olarak kötü kolesterol kaynağı olarak gördükleri $(\% 58,9)$ tespit edilmiştir.

Katılımcıların karbonhidrat/şeker ile ilgili sorulara verdiği cevaplara göre \%54,5 doğru, \%45,5 oranında yanlış bilgiye sahip oldukları keşfedilmiştir. Karbonhidrat ile ilgili bilgi düzeylerinin yüksek olduğu $(\% 68,4)$, özellikle esmer şekerin beyaz şekerden daha sağlıklı olduğuna dair \%85,9 oranında yanlış bilgiye sahip oldukları görülmüştür.

Proteinlerle ilgili sorulara göz atıldı̆̆ı zaman, katılımcıların \%65,8 oranında doğru bilgiye sahip oldukları görülmektedir. Et, balık, yumurta ve sütün protein açısından faydalarının doğru bilindiği $(\% 93,4)$, sebzelerin de protein kaynağı olduğunun ise $(\% 66,1)$ yeterince bilinmediği ortaya konulmuştur.

Tuz ile ilgili sorulara bakıldı̆̆ı zaman da katılımcılar arasında doğru bilgiye sahip olma oranının \%47,1 seviyesinde kaldığı görülmektedir. Özellikle günlük tuz tüketiminin 10 gramı geçmemesi gerektiğinin \%90,8 oranında yanlış bilindiği görülmektedir. Katılımcıların, gıda etiketlerinde yer alan sodyum klorür ifadesinin tuz anlamına geldiğini \%73,9 oranında doğru bildikleri ortaya çıkmıştır.

Vitaminler konusunda katılımcıların, \%66,4 oranında doğru bilgiye sahip oldukları tespit edilmiştir. Özellikle C ve B vitaminleri konusunda (\%69) farkındalığın yüksek olduğu söylenebilir.

Katılımcıların liflerle ilgili sorularda \%63 oranında doğru bilgiye sahip oldukları görülmektedir. Lifli gıdaların tokluk hissi vermede $(\% 67,2)$ ve sindirim sitemine katkısının $(\% 67,2)$ doğru bilindiği, lifli gıdaların kan kolesterolü ve kan şekerini düzenlemeye katkısının yeterince $(\% 47,1)$ bilinmediği görülmektedir. 
Katılımcların etiket bilgileri içerisinde $\% 60,6$ oranı en çok dikkat ettikleri bilginin katkı maddeleri olmasına rağmen, katkı maddeleri ile ilgili sorularda \%67,8 oranında yanlış bilgiye sahip oldukları görülmektedir. Özellikle “E” kodu ile başlayan g1da maddelerinin insan sağlığına zararlıdır gibi bir yanlış düşünceye sahip olan katılımcıların \%88,5 olması düşündürücüdür. Oysaki bir katkı maddesine E kodunun verilmiş olması Avrupa Birliği ve Avrupa Gıda Katkıları ve Gıda Enzimleri Federasyonunca güvenli bulunduğu anlamına da gelmektedir (Winter, 2009:106). Buradaki amaç katkı maddelerini sınıflandırarak tüketicilere bilgi vermektir.

\section{DEĞERLENDİRME VE SONUÇ}

Günümüzün genç bireylerinin geleceğimizin yetişkinleri olacağı göz önünde alındığı zaman çalışmanın önemi daha da öne çıkmaktadır. Elde edilen sonuçlarına göre, gençlerin paketli g1da etiketlerinde yer alan protein $(65,8)$, vitamin $(64,4)$, lifli g1da $(\% 63,0)$, yağ $(\% 55,3)$ ve enerji $(\% 50,7)$ bilgileri hakkında daha fazla bilgiye sahip oldukları; katkı maddeleri $(\% 32,2)$, karbonhidrat / şeker $(\% 45,5)$ ve tuz $(\% 47,1)$ hakkında ise daha az bilgiye sahip oldukları tespit edilmiştir.

Araştırmaya katılan gençlerin en çok dikkat ettiği gıda etiketi bilgi grubunun katkı maddeleri olması $(\% 60,6)$, ancak katkı maddeleri hakkında genel bilgisinin $(\% 32,2)$ de en az olduğu soru grubunun da katkı maddeleri olması düşündürücü olup, aynı zamanda çalışmanın önemini ortaya koymaktadır. Buradan hareketle toplumu oluşturan bireylerde, gıda okuryazarlığın erken yaşlarda oluşturulması sağlıklı toplum oluşturma hedefine ulaşmaya olumlu katkılar yapacaktır. Bu bağlamda elde edilen sonuçların da gösterdiği üzere özellikle doymuş ve doymamış yağlar, esmer şeker, sebzelerin içerdiği protein, günlük tüketilmesi gereken tuz miktarı, katkı maddelerinin sınıflandırılması konusundaki yanlış bilgilerin ivedilikle düzeltilmesi önem arz etmektedir.

Bu bağlamda, Türk Gıda Kodeksi Gıda Etiketleme ve Tüketicileri Bilgilendirme Yönetmeliği'ne göre paketli g1da etiketlerinde yer alan bilgilerin doğru anlaşılıp, yorumlanmasının sağlıklı gıda satın alma tercihi oluşturmada katkısı olacağı açıktır. Gıda etiketi okuryazarlığı becerisinin kazandırılması için gerekli çabaların eğitim sistemi içerisine konumlandırılmasında fayda görülmektedir. Sağlıklı beslenme 
düşüncesinin gelişmesiyle beraber paketli gıda üreticilerinin de kanuni zorunluluğun yanında tüketicilere eğitici olması için de bilgiler vermesi ürünlerinin tercih edilebilirliğini arttıracaktır. Bütüncül açıdan sağlanacak geliştirmelerin tüketicilerin satın alma süreçlerine de pozitif katkı sağlayacağı ve planlı satın alma davranışına yön vereceği beklenebilir.

Çalışmanın temel amacı toplum ve akademi içerisinde bu konuya dikkat çekmek olup gıda etiketi okumaktan çok gıda etiketinin doğru okunmasını sağlamaya yöneliktir. Daha önce de vurgulandığı üzere çalışma; Türk Gıda Kodeksi Gıda Etiketleme ve Tüketicileri Bilgilendirme Yönetmeliği'ne göre uyarlanmıştır. Gıda okuryazarlığı seviyesine dikkat çekmek amacıyla yapılan çalışmanın bu alanda işlevsel bir ölçeğin geliştirilmesi açısından da yararlı olacağı düşünülmektedir.

Gelecek çalışmalarda; tüketicilerin etiket okuma/okumama davranışlarının bazı demografik, sosyo-ekonomik grupsal değişkenler yanında; planlı satın alma kuramı gibi bazı sosyal kuramlarla ilişkilendirilerek bu konuda uzmanlık sağlanabilir. Diğer taraftan, gıda etiketi okuma davranışı gösterenler ile göstermeyenlerin hastalıklara karşı durumlarının incelenmesine yönelik çalışmaların yapılması da gıda okuryazarlığı konusunun sağlık açısından öneminin kavranılmasına yardımcı olacağı düşünülmektedir. 


\section{KAYNAKÇA}

Aktaş, N. ve Özdoğan, Y. (2016). Gıda ve beslenme okuryazarlı̆̆ı. Harran Tarım ve Gıda Bilimleri Dergisi, 20(2), 146-153.

Azman, N. ve Sahak, S. Z. (2014). Nutritional label and consumer buying decision: a preliminary review, Procedia-Social and Behavioral Sciences, 130, 490-498.

Dickson-Spillmann, M., Siegrist, M. ve Keller, C. (2011). Development and validation of a short, consumer-oriented nutrition knowledge questionnaire, Appetite, 56(3), 617-620.

Drichoutis, A. C., Lazaridis, P. ve Nayga Jr, R. M. (2006). Consumers' use of nutritional labels: a review of research studies and issues, Academy of Marketing Science Review, 2006, 1-22.

FAO ve WHO. Codex Strategic Plan 2020-2025. Erişim adresi:http://www.fao.org/3/ca5645en/CA5645EN.pdf

Grunert, K. G., Wills, J. M. ve Fernández-Celemín, L. (2010). Nutrition knowledge, and use and understanding of nutrition information on food labels among consumers in the UK, Appetite, 55(2), 177-189.

Lewis, J. 2019. Codex nutrient reference values. Rome. FAO and WHO.

Lobstein, T., Jackson-Leach, R., Moodie, M. L., Hall, K. D., Gortmaker, S. L., Swinburn, B. A., James, W.P.T., Wang, Y. ve McPherson, K. (2015). Child and adolescent obesity: part of a bigger picture. The Lancet, 385(9986), 2510-2520.

Miller, L. M. S. ve Cassady, D. L. (2015). The effects of nutrition knowledge on food label use: A review of the literature, Appetite, 92, 207-216.

Parmenter, K. ve Wardle, J. (1999). Development of a general nutrition knowledge questionnaire for adults, European Journal of Clinical Nutrition, 53(4), 298-308.

Post, R. E., Mainous III, A. G., Diaz, V. A., Matheson, E. M. ve Everett, C. J. (2010). Use of the nutrition facts label in chronic disease management: results from the National Health and Nutrition Examination Survey, Journal of the American Dietetic Association, 110(4), 628-632.

Ronto, R., Ball, L., Pendergast, D. ve Harris, N. (2016). Adolescents' perspectives on food literacy and its impact on their dietary behaviours, Appetite, 107, 549-557.

Slater, J., Falkenberg, T., Rutherford, J. ve Colatruglio, S. (2018). Food literacy competencies: A conceptual framework for youth transitioning to adulthood. International Journal of Consumer Studies, 42(5), 547-556.

Türk gıda kodeksi gida etiketleme ve tüketicileri bilgilendirme yönetmeliği. (2017, 26, Ocak). Resmi Gazete (Sayı: 29960 (Mükerrer)). Erişim adresi:

https://www.resmigazete.gov.tr/eskiler/2017/01/20170126M1-6.htm

TUIK, 2019. Erişim adresi: https:// biruni.tuik.gov.tr/medas/?kn=95\&locale=tr 
Vidgen, H. A. ve Gallegos, D. (2012). Defining food literacy, its components, development and relationship to food intake: A case study of young people and disadvantage. School of Exercise and Nutrition Sciences Faculty of Health, Queensland University of Technology, Australia.

Erişim adresi: https://eprints.qut.edu.au/53786/1/Food_literacy_and_young_people_report.pdf

Wardle, J., Parmenter, K. ve Waller, J. (2000). Nutrition knowledge and food intake, Appetite, 34(3), 269275.

Winter, R. (2008). A consumer's dictionary of food additives. New York, Three Rivers Press.

Yılmaz V. (2019). Türkiye'de kentsel dönüşüm sürecinin yansımaları ve kentleşme, Van Yüzüncü Yıl Üniversitesi İktisadi ve İdari Bilimler Fakültesi Dergisi, 4(7), 119-134. 